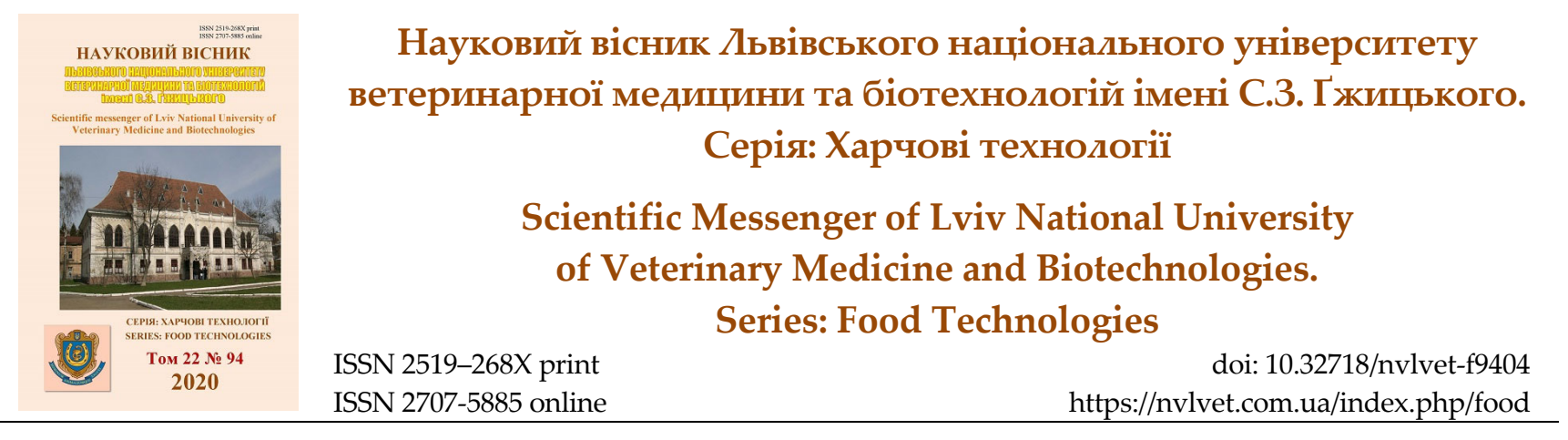

UDC 621.37:637.142

\title{
A2 milk as an alternative to goat milk in yoghurt production
}

\author{
V. Ladyka, M. Samilyk, L. Ladyka, A. Helikh, N. Bolgova \\ Sumy National Agrarian University, Sumy, Ukraine
}

Article info

Received 01.09.2020

Received in revised form 01.10 .2020

Accepted 02.10.2020

Sumy National Agrarian University, G. Kondratieva Str., 160, Sumy, 40021, Ukraine.

Tel.: +38-066-378-67-39

E-mail:m.samilyk@ukr.net
Ladyka, V., Samilyk, M., Ladyka, L., Helikh, A., \& Bolgova, N. (2020). A2 milk as an alternative to goat milk in yoghurt production. Scientific Messenger of Lviv National University of Veterinary Medicine and Biotechnologies. Series: Food Technologies, 22(94), 18-22. doi: 10.32718/nvlvetf9404

The article discusses and analyzes the prospects for the use of cow's milk A2 as an alternative to goat milk in the production of yoghurt. It has been analyzed that goat's milk is less allergenic than cow's milk. The genotype of A1 and A2 milk samples was determined using molecular biological analysis of allele recognition by polymerase chain reaction (PCR) in real time. The organoleptic characteristics of yoghurts made from cow's milk A1, A2, goat's milk, from a mixture of goat's and cow's milk of different genotypes were studied and presented in the work in the form of a profile analysis using the significance coefficients of each individual descriptor (color, smell, taste, appearance and consistency). The physicochemical parameters (protein and fat content) of yoghurts made from cow's milk A1, A2, goat's milk, from a mixture of goat's and cow's milk of different genotypes were determined. High fat and protein content was found in sample № 3 made from goat milk. The protein content is $3.99 \mathrm{~g}$ per $100 \mathrm{~g}$ of product, fat-4.1 g per $100 \mathrm{~g}$ of product. Sample No. 2 is made from A2 cow's milk contains $0.5 \mathrm{~g}$ per $100 \mathrm{~g}$ of product less protein and $0.6 \mathrm{~g}$ per $100 \mathrm{~g}$ of product less fat than sample No. 1 made from Al cow milk. The best result in terms of protein and fat content in the sample of yogurt № 4, made from a mixture of cow and goat milk. This paper presents a comparative analysis of the energy value of yoghurts based on cow's milk A1, A2, goat's milk, from a mixture of goat's and cow's milk of different genotypes. It should be noted that the highest numerical values of the level of balance in terms of organoleptic indicators and energy value were obtained by samples of yoghurts made from a mixture of cow's A2 milk and goat's milk. Studies have shown that yoghurts made from a mixture of goat and cow milk meet the requirements of the standard.

Key words: A2 cow's milk, A1 cow's milk, goat's milk, yogurt, physical and chemical indicators, organoleptic indicators.

\section{Молоко А2 як альтернатива козиному у виробництві йогуртів}

\author{
В. І. Ладика, М. М. Самілик, Л. М. Ладика, А. О. Геліх, Н. В. Болгова
}

Сумський національний аграрний університет, м. Суми, Україна

\footnotetext{
У статті розглянуто та проаналізовано перспективи використання молока коров 'ячого А2 як альтернативи козиному у виробництві йогуртів. Показано, шьо козине молоко є менш алергенним на відміну від коров'ячого. Визначено генотип зразків молока А1 та А2 за допомогою молекулярно-біологічного аналізу розпізнавання алелей методом полімеразно ланцюгової реакиії (ПлР) у реальному часі. Досліджено органолептичні показники йогуртів, виготовлених з молока коров'ячого А1, А2, козиного молока, з суміші козиного та коров 'ячого молока різних генотипів та подано в роботі у вигляді профільного аналізу з використанням коефіиієнтів вагомості кожного окремого дескриптора (колір, запах, смак, зовнішній вигляд та консистенція). Визначено фізико-хімічні показники (вміст білка та жиру) йогуртів, виготовлених з молока коров 'ячого А1, А2, козиного молока, суміші козиного та коров 'ячого молока різних генотипів. Найвищий вміст жиру та білка виявлено у зразку № 3, виготовленому із козиного молока. Вміст білка становить 3,99 г на 100 г продукту, жиру - 4,1 г на 100 г продукту. Зразок № 2, виготовлений із молока коров'ячого А2, містить на 0,5 г на 100 г продукту менше білка та 0,6 г на 100 г продукту менше жиру, ніж зразок № 1, виготовлений із молока коров'ячого А1. Найкрашиий результат за вмістом білка та жсиу у зразку йогурту № 4, виготовленого із суміші коров'ячого А2 та козиного молока. У даній роботі наведено порівняльний аналіз енергетичної цінності йогуртів на основі молока коров 'ячого А1, А2,
} 
козиного молока, з суміші козиного та коров'ячого молока різних генотипів. Варто зазначити, щзо найвищі чисельні значення рівня збалансованості за органолептичними показниками та енергетичною цінністю отримали зразки йогуртів, виготовлені з суміші молока коров'ячого А2 та козиного. Проведені дослідження показали, щчо йогурти, виготовлені із суміші козиного і коров'ячого молока, відповідають вимогам стандарту.

Ключові слова: молоко А2 коров'яче, молоко А1 коров'яче, молоко козине, йогурт, фізико-хімічні показники, органолептичні показники.

\section{Вступ}

Існують певні переваги козиного молока над коров'ячим, зокрема краща засвоюваність, гіпоалергенність, регулювання обміну речовин (Ryzhkova et al., 2019).

Зростання виробництва і споживання козиного молока пояснюють 4 основними факторами:

1) приростом загальної чисельності населення Землі й відповідно збільшенням потреби в їжі та використанні сільськогосподарської сировини;

2) підвищеним попитом на продукти для здорового харчування;

3) альтернативою для людей, які страждають харчовою алергією і (або) гостроінтестинальними розладами;

4) наявністю ряду цікавих характеристик фракційного складу і фізико-хімічних особливостей (Skidan et al., 2015).

Козине молоко має меншу концентрацію $\alpha_{\mathrm{s}} 1$ казеїну, що сприяє кращому перетравленню і знижує можливість неприємних алергічних реакцій в організмі людини (Fatihov \& Haertdinov, 2017). Козине молоко має тільки А2 форму $\beta$-казеїну (Fatihov \& Haertdinov, 2017), який вважається кориснішим через відсутність пептидів, що викликають у людей алергію (Gorlov et al., 2016). Відомо, що клінічні прояви, пов'язані зі споживанням коров'ячого молока, часто мають неалергічну природу. Сенсибілізація до $\beta$ казеїну спостерігається лише у 66,7 \% пацієнтів 3 алергією на коров'яче молоко (Fedotova et al., 2011).

На відміну від коров'ячого, козине молоко не викликає генетично зумовленої атипової реакції до деяких неспецифічних подразників (ідіосинкразії) (Jenness \& Parkash, 1990). Козине молоко збагачує молочну основу сироватковими білками та надає продукту гіпоалергенні властивості (Didukh \& Romanchenko, 2010).

Незважаючи на такі очевидні позитивні фактори, козине молоко не користується великою популярністю серед споживачів. Це пов'язано з його специфічними органолептичними характеристиками. Характерний «козиний» смак та аромат стримує його широке використання для переробки на великий асортимент питного молока та молочних продуктів.

Козине молоко рекомендовано як альтернативу коров'ячому пацієнтам, що страждають на алергію на коров'яче молоко, оскільки вони добре переносять козине (Park \& Haenlein, 2007). Основним компонентом казеїнової фракції козиного молока $є \beta$-казеїн, тимчасом як $\alpha_{\mathrm{s}} 1$-казеїн $\epsilon$ основним казеїном у коров'ячому молоці (Park \& Haenlein, 2007).

$\beta$-казеїн існує в молоці як тип A1 або А2, що розрізняються амінокислотною послідовністю. Тип А1 містить гістидин в положенні 67 амінокислотної пос- лідовності $\beta$-казеїну, тимчасом як тип А2 містить пролін в цьому положенні (Jung et al., 2017).

$\beta$-казоморфін (ВСМ-7), який утворюється в результаті протеолітичного розщеплення $\beta$-казеїну типу A1, може викликати різні порушення, такі як шлунково-кишкові. Однак козиний $\beta$-казеїн в основному складається 3 типу А2 і може розглядатися як безпечний харчовий продукт (Jung et al., 2017). Таким чином, фракція $\beta$-казеїну А2 не тільки має поліпшену засвоюваність і гіпоалергенні властивості, а й може мати потенціал як функціональний харчовий матеріал (Jung et al., 2017).

При розщепленні ферментами шлунковокишкового тракту молока, що містить фракцію $\beta$ казеїну A1 (отриманого від корів з генотипом A1A1 i A1A2), утворюється опіоїдний пептид $\beta$-казоформін 7 (BCM-7) в значно більшій кількості, ніж при відповідному розщепленні молока, що містить фракцію $\beta$ казеїну А2 (отриманого від корів з генотипом А2А2) (Kamiński et al., 2007).

Вважається, що ті чи інші негативні симптоми при вживанні молока і молочних продуктів спостерігаються у 30\% населення (Kovaljuk et al., 2018). В молоці з варіантом А1 $\beta$-казеїну рівень ВСМ-7 в 4 рази вищій, ніж в молоці А2 (Bell et al., 2016).

Проте обсяги виробництва козиного молока в Україні станом на 2020 рік становить 50 тисяч тонн, а обсяги виробництва молока коров'ячого - 10,1 млн тонн. 3 огляду на практичну складову, економічну доцільність та затребуваність на споживчому ринку гіпоалергенних молочних продуктів постає завдання дослідити та обгрунтувати можливість виробництва продукції на основі молока А2 на прикладі йогурту.

3 огляду на це, метою наших досліджень стало обгрунтування можливості та доцільності виготовлення йогуртів із гіпоалергенними та ідіосинкразійними властивостями з молока коров'ячого А2, альтернативного козиному.

Для досягнення поставленої мети необхідно було вирішити такі завдання:

1. Визначити генотип зразків молока коров'ячого А2 і А1 та відібрати окремі партії за генотипом для використання у технології йогуртів;

2. Дослідити органолептичні та фізико-хімічні показники йогуртів, виготовлених 3 молока коров'ячого A1, A2, козиного молока, із суміші козиного та коров'ячого молока різних генотипів та подати у вигляді профільного аналізу;

3. Розрахувати енергетичну цінність йогуртів на основі молока коров'ячого A1, А2, козиного молока, суміші козиного та коров'ячого молока різних генотипів;

4. Довести, що йогурти, виготовлені із молока коров'ячого А2, за основними показниками (органолептичними та фізико-хімічними) можна вживати 
альтернативними йогуртам, що виготовлені на основі козиного молока.

\section{Матеріал і методи досліджень}

Досліджувані зразки виготовлялися за традиційною технологією термостатним способом із незбираного молока відповідно до вимог ДСТУ 4343:2004 “Йогурти. Загальні технічні умови” (DSTU
4343:2004, 2005). Паралельно готували шість зразків йогурту із молока коров'ячого A1, A2, козиного молока, суміші коров'ячого та козиного молока (табл. 1). Ферментацію проводили сухою бактеріальною закваскою "Йогурт Vivo" (ТУУ 15.5-30603000636001:2009) за температури $(37 \pm 1)^{\circ} \mathrm{C} \quad$ (дана температура рекомендована виробником закваски). Під час сквашування контролювали титровану кислотність згідно з ГОСТ 3624 та температуру.

Таблиця 1

Склад досліджуваних зразків (в г на 100 г продукту без урахування втрат)

\begin{tabular}{ccccc}
\hline Найменування & \multicolumn{4}{c}{ Склад зразка } \\
\cline { 2 - 5 } зразка & Молоко коров'яче А1 & Молоко коров'яче А2 & Молоко козине & Бактеріальна закваска \\
\hline Зразок 1 & 100 & - & - & 0,1 \\
Зразок 2 & - & 100 & - & 0,1 \\
Зразок 3 & - & - & 100 & 0,1 \\
Зразок 4 & - & 50 & 50 & 0,1 \\
Зразок 5 & - & 75 & 25 & 0,1 \\
Зразок 6 & 50 & - & 50 & 0,1 \\
\hline
\end{tabular}

Визначення генотипу зразків молока здійснювали за допомогою молекулярно-біологічного аналізу розпізнавання алелей (TU U 01.4-04718013-001:2020) методом полімеразно ланцюгової реакції (ПЛР) у реальному часі.

Пастеризацію молока здійснювали при температуpi 90-94 ${ }^{\circ} \mathrm{C}$ з витримкою протягом 2-3 хвилини. Підвищений режим пастеризації необхідний для поліпшення консистенції та забезпечення повного знищення сторонньої мікрофлори, руйнування ферментів. Сквашування проводилося у термостатній камері при температурі $40-45^{\circ} \mathrm{C}$ протягом 6 годин.

Якість готового йогурту оцінювали за органолептичними та фізико-хімічними показниками. Смак, запах, колір, консистенцію визначали органолептично, масову частку жиру за ДСТУ ISO 2446:2019 (ISO 2446:2008, IDT) (DSTU ISO 2446:2019), масову частку сухих знежирених речовин за ДСТУ 8552:2015 (DSTU 8552:2015), загальний білок визначали методом К'єльдаля, вміст вуглеводів - поляриметричним методом.

Для наочного сприйняття результатів побудовано профілографу розроблених зразків (рис. 1), що дає можливість виявити оптимальний зразок.

Дегустацію проведено експертною комісією у складі 10 осіб. При цьому оцінювалися дескриптори, які $\epsilon$ значущими для споживачів і регламентуються вимогами діючої нормативної документації (DSTU 4343:2004, 2005). Дегустаційну оцінку зразків йогурту проведено за 5-бальною шкалою бажаності та інтенсивності відчуття смакових і ароматичних властивостей продукту. Результати аналізу подано у вигляді профільного аналізу 3 використанням коефіцієнтів вагомості кожного окремого дескриптора (колір, запах, смак, зовнішній вигляд та консистенція). Порівняння проводилося між досліджуваними зразками.

Встановлено, що найбільш гармонійний та властивий смак 3 інтенсивністю в 4,6 бала притаманний йогуртам, виготовленим із суміші коров'ячого молока A2 та козиного молока (зразки 4 та 5).

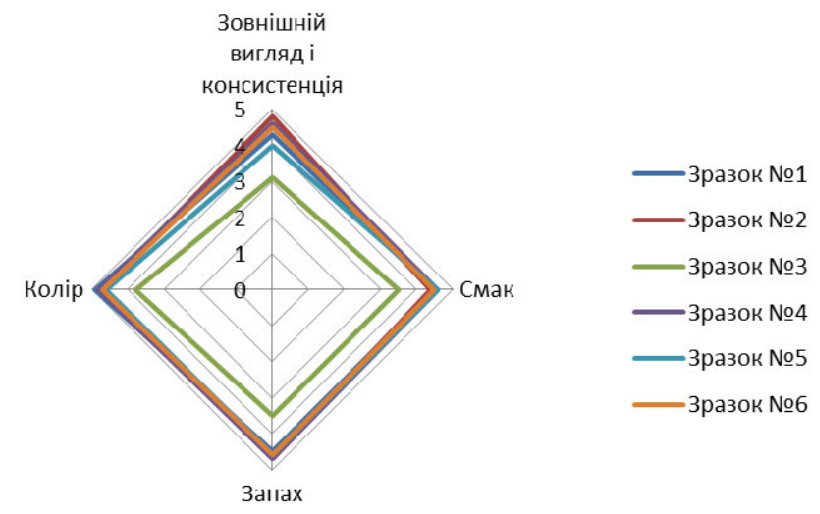

Рис. 1. Органолептичний профіль досліджуваних зразків

За ароматом досить високу інтенсивність позитивних характеристик (4,7 бала) мали зразок № 2 (виготовлений із молока коров'ячого А1) та зразок № 4 (виготовлений із $50 \%$ молока коров'ячого А2 та $50 \%$ козиного молока). Решта, крім зразка № 3, мали однаково добрі відгуки. У зразку № 3 відчувався характерний козиний запах.

Йогурти, отримані з коров'ячого молока, мали білувато-кремове забарвлення, всі зразки відповідали вимогам стандарту. Зразок, виготовлений із $100 \%$ козиного молока, відрізнявся від інших занадто білим забарвленням.

У йогурті, виготовленому із $100 \%$ козиного молока (зразок № 3) мікрофлора закваски не набула нормального розвитку. Тому отриманий напій мав занадто рідку, нехарактерну для йогурту, консистенцію. Дешо рідка консистенція спостерігалася і в інших зразках, виготовлених із додаванням козиного молока. Найвищу оцінку за зовнішнім виглядом і консистенцією, у 4,8 бала, отримав зразок, виготовлений із коров'ячого молока А2.

Результати дегустаційної оцінки показали, що отримані зразки, крім зразка № 3 (виготовленого із 100 \% козиного молока), характеризувалися збалансо- 
ваним смаком, приємним кольором та консистенцією відповідали вимогам нормативної документацією (DSTU 4343:2004, 2005).

Проведено дослідження вмісту білка у зразках йогуртів, виготовлених 3 молока коров'ячого А1, А2, козиного молока, суміші козиного та коров'ячого молока різних генотипів. Результати досліджень показано на рисунку 2.

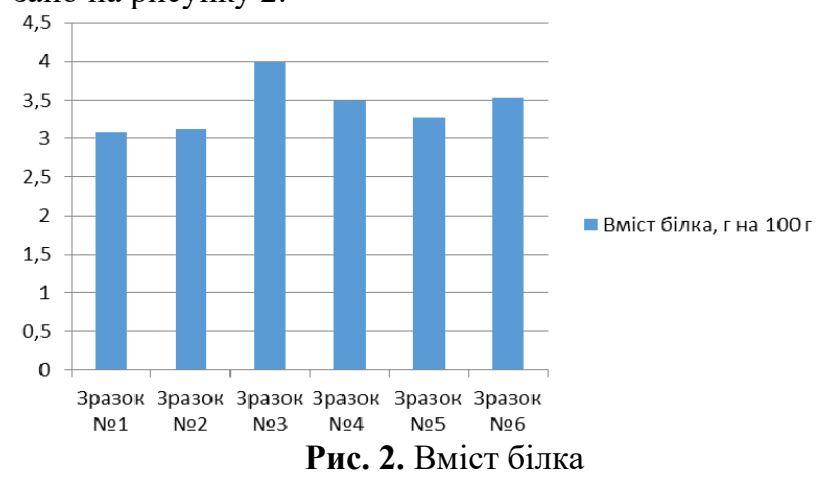

Дані графіка на рисунку 2 мають чітку відмінність. Зокрема, найвищий вміст білка виявлено у зразку № 3, виготовленому із козиного молока, що становить 3,99 г на 100 г продукту. Зразок № 2, виготовлений із молока коров'ячого А2, містить на 0,5 г на 100 г продукту більше білка, ніж зразок № 1, виготовлений із молока коров'ячого А1. Найкращий результат за вмістом білка виявлено у зразку № 4, виготовленому із суміші коров'ячого А2 (50 \%) та козиного молока $(50 \%)$.

Проведено дослідження вмісту жиру у зразках йогуртів, виготовлених 3 молока коров'ячого А1, А2, козиного молока, суміші козиного та коров'ячого молока різних генотипів. Результати досліджень показано на рисунку 3.

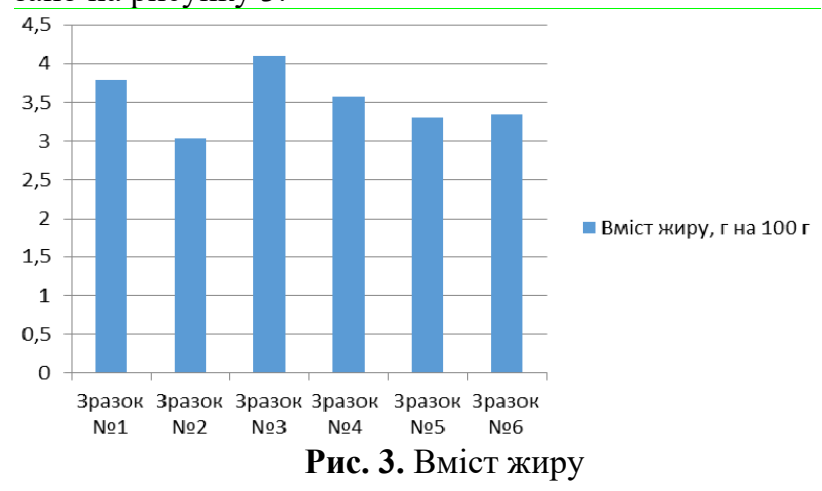

Аналіз даних, наведених на графіку (рис. 3), показав, що найвищий вміст жиру виявлено у зразку № 3, виготовленому із козиного молока, і становить 4,1 г на 100 г продукту. Зразок № 2, виготовлений із молока коров'ячого A2, містить на 0,6 г на 100 г продукту менше білка, ніж зразок № 1, виготовлений із молока коров'ячого A1. Найкращий результат за вмістом жиру виявлено у зразку № 4, виготовленому із суміші коров'ячого А2 (50 \%) та козиного молока (50\%).

За результатами визначення вмісту білків, жирів та вуглеводів визначали поживну (харчову) цінність зразків.
Для розрахунку енергетичної цінності йогурту застосовували таку формулу:

$\mathrm{E}=\mathrm{k} \sigma \times(\mathrm{M \sigma}+\mathrm{Mв})+\mathrm{k} \sigma \times \mathrm{Mж,}$

де $\mathrm{E}$ - енергетична цінність, ккал;

Мб - масова частка білка, г/100 г продукту;

Мв - масова частка вуглеводів, г/100 г продукту;

Мж - масова частка жиру, г/100 г продукту;

kб = 4 - коефіцієнт енергетичної цінності 1 г білка чи 1 г вуглеводів у продукті, ккал/г;

kж $=9$ - коефіцієнт енергетичної цінності 1 г жиру в продукті, ккал/г.

Енергетична цінність зразків показана на рис. 4.

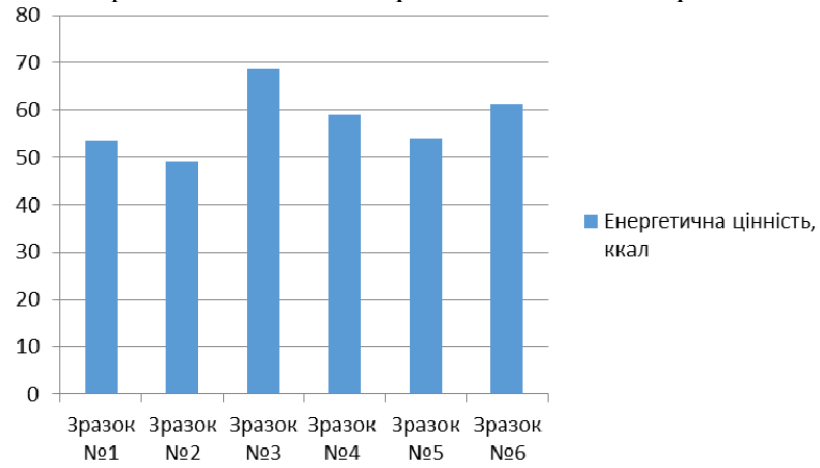

Рис. 4. Енергетична цінність продуктів

3 графіка на рис. 4 чітко видно, що зразок йогурту № 3, виготовлений 3 козиного молока, має найвищу енергетичну цінність. Це обумовлено найвищим умістом жиру в молочній сировині порівняно зі зразками № 1 та № 2. Із зразків-сумішей найвищу енергетичну цінність має зразок йогурту № 6, виготовлений із суміші молока A1 (50\%) та козиного (50\%). Але за вимогами діючого стандарту найкращий результат показав зразок № 4, виготовлений із суміші молока коров'ячого A2 (50 \%) та козиного (50 \%).

\section{Висновки}

Визначено генотип зразків молока коров'ячого А2 i А1 та відібрано окремі партії за генотипом для використання у технології йогуртів.

Досліджено органолептичні та фізико-хімічні показники йогуртів, виготовлених із молока коров'ячого A1, А2, козиного молока, суміші козиного та коров'ячого молока різних генотипів та подано у вигляді профільного аналізу. Визначено, що найбільш гармонійний та властивий смак 3 інтенсивністю в 4,6 бала, притаманний йогуртам, виготовленим із суміші коров'ячого молока А2 та козиного молока (зразки 4 та 5). Найвищий вміст жиру та білка виявлено у зразку № 3, виготовленому із козиного молока. Вміст білка становить 3,99 г на 100 г продукту, жиру - 4,1 г на 100 г продукту. Зразок № 2, виготовлений із молока коров'ячого A2, містить на 0,5 г на 100 г продукту менше білка та 0,6 г на 100 г продукту менше жиру, ніж зразок № 1, виготовлений із молока коров’ячого A1. Найкращий результат за вмістом білка та жиру виявлено у зразку йогурту № 4, виготовленому із суміші коров'ячого (50 \%) та козиного молока (50 \%).

Розраховано енергетичну цінність йогуртів на основі молока коров'ячого A1, А2, козиного молока, 
суміші козиного та коров'ячого молока різних генотипів. Зі зразків-сумішей найвищу енергетичну цінність має зразок йогурту № 6, виготовлений із суміші молока A1 (50 \%) та козиного (50 \%). Але, відповідно до вимог діючого стандарту, найкращий результат показав зразок № 4, виготовлений із суміші молока коров'ячого А2 (50 \%) та козиного (50 \%).

Доведено, що йогурти, виготовлені із молока коров'ячого А2, за всіма основними показниками (органолептичними та фізико-хімічними) можуть бути альтернативою йогуртам, виготовленим на основі козиного молока.

Перспективи подальших досліджень. Подальші дослідження будуть спрямовані на визначення впливу молока різних генотипів на алергічні прояви у людей.

\section{References}

Bell, S. J., Grochoski, G. T., \& Clarke, A. J. (2016). Health implications of milk containing beta-casein with the A2 genetic variant. Review Crit Rev Food Sci Nutr, 46(1), 93-100 doi: 10.1080/10408390591001144.

Didukh, N. A., \& Romanchenko, S. V. (2010). Obgruntuvannia parametriv fermentatsii molochnoi osnovy u biotekhnolohii kefiru dytiachoho kharchuvannia. Kharchova nauka i tekhnolohiia, 2, 30 33. URL: http://nbuv.gov.ua/UJRN/Khnit_2010_2_11 (in Ukrainian).

DSTU 4343:2004 (2005). Yohurty. Zahalni tekhnichni umovy. Kyiv (in Ukrainian).

DSTU 8552:2015 (2016). Moloko ta molochni produkty. Metody vyznachannia volohy i sukhoi rechovyny rechovyn. Kyiv (in Ukrainian).

DSTU ISO 2446:2019 (ISO 2446:2008, IDT). Moloko. Vyznachennia vmistu zhyru. Kyiv, 2019 (in Ukrainian).

Fatihov, A. G., \& Haertdinov, R. A. (2017). Vlijanie urovnja soderzhanija $\alpha$ s1- i $\beta$ - kazeinov v koz'em moloke na ego allergennye, termostabil'nye i syrodel'cheskie svojstva. Uchenye zapiski Kazanskoj gosudarstvennoj akademii veterinarnoj mediciny im. N. Je. Baumana, 2(230), 163-167. URL: https://readera.org/ 14288931 (in Russian).

Fedotova, M. M., Ogorodova, L. M., Fèdorova, O. S., \& Evdokimova, T. A. (2011). Molekuljarnye i jepidemio-logicheskie osnovy allergii $\mathrm{k}$ belkam korov'ego moloka. Bjulleten' sibirskoj mediciny, 10(6), 86-92. doi: 10.20538/1682-0363-2011-6-86-92.
Gorlov, I. F., Sycheva, O. V., \& Kononova, L. V. (2016). Beta-kazein: izvestnyj, no ne poznannyj. Molochnoe i mjasnoe skotovodstvo, 6, 18-19. URL: http://www.skotovodstvo.com/BETA-KAZEINIZVESTNYI\%2C-NO-NE-POZNANNYI-STR-18-/ (in Russian).

Jenness, R., \& Parkash, S. (1990). Lack of a fat globule clustering agent in goats milk. J. Dairy Sci., 54(1), 123-124. doi: 10.3168/jds.S0022-0302(71)85790-9.

Jung, T.-H., Hwang, H.-J., Yun, S.-S., Lee, W.-J., Kim, J.-W., Ahn, J.-Y., Jeon, W.-M., \& Han, K.-S. (2017). Hypoallergenic and Physicochemical Properties of the A2 $\beta$-Casein Fractionof Goat Milk. Korean Journal for Food Science of Animal Resources, 37(6), 940-947. doi: 10.5851/kosfa.2017.37.6.940.

Kamiński, S., Cieslińska, A., \& Kostyra, E. (2007). Polymorphism of bovine beta-casein and its potential effect on human health. J Appl Genet, 48(1), 89-98. doi: 10.1007/BF03195213.

Kovaljuk, N. V., Sacuk, V. F., Machul'skaja, E. V., \& Shahnazarova, Ju. Ju. (2018). Proizvodstvo moloka A2 - perspektivnoe napravlenie povyshenija rentabel'nostiiotrasli molochnogo skotovodstva. Tematicheskij nomer "Genetika i plemennoe delo", 5, 22-23. URL: https://cyberleninka.ru/article/n/proizvodstvo-molokaa2-perspektivnoe-napravlenie-povysheniyarentabelnosti-otrasli-molochnogo-skotovodstva/viewer (in Russian),

Park, Y. W., \& Haenlein, G. F. W. (2007). Goat Milk, Its Products and Nutrition. In Y. H. Hui, Ed. John Wiley \& Sons, Inc. Handbook of Food Products Manufacturing (rr. 447-486). New York, NY.

Ryzhkova, T. N., Dyukareva, G. I., Heyda, I. M., \& Goncharova, I. I. (2019). Comparative characteristics of physical and chemical indices of goat and cows milk for commercial use. Veterinary science, technologies of animal husbandry and nature management, 3, 213-224. doi: 10.31890/vttp.2019.03.29.

Skidan, I. N., Guljaev, A. E., \& Kaznacheev, K. S. (2015). Zhirovye globuly kak determinanty pishhevoj i biologicheskoj cennosti koz'ego moloka. Voprosy pitanija, 84(2), 81-95. URL: http://voprosypitaniya.ru/ru/jarticles_diet/350.html?SSr=2401339 ee421ffffffff 27c_07e0021c15181d-538 (in Russian).

TU U 01.4-04718013-001:2020 (2020). Moloko A2 nezbyrane. Tekhnichni umovy. Sumy (in Ukrainian). 